134

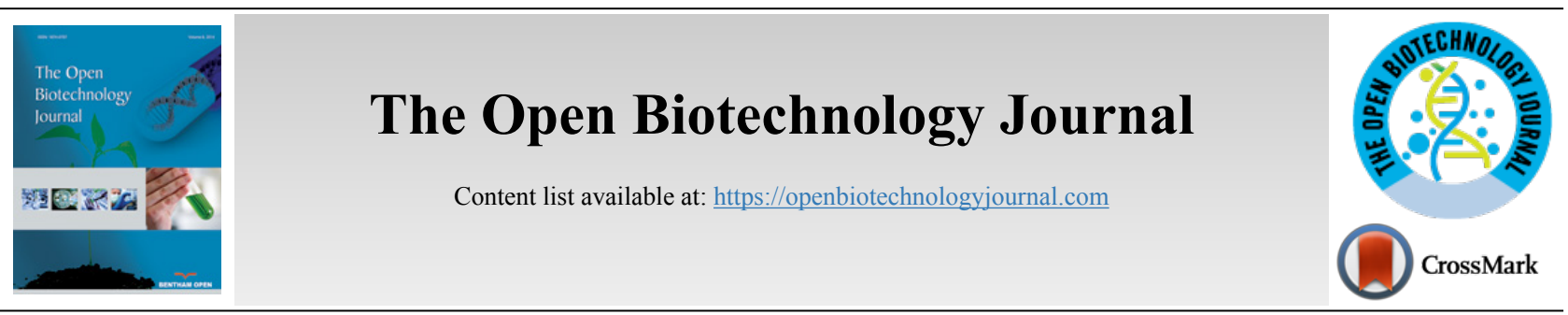

REVIEW ARTICLE

\title{
Review on Mineral Nutrition of Onion (Allium cepa L)
}

\author{
Getachew Amare, \\ ${ }^{\prime}$ Department of Horticulture, College of Agriculture and Natural Resources Sciences, Debre Berhan University, Debre Berhan, P.O. Box: 445, \\ Ethiopia
}

\begin{abstract}
:
Proper nutrition is one of the factors which is limiting onion production. Onion yield and quality is affected by fertilization of macro and micro nutrients. Mineral nutrients, Nitrogen, phosphorous and Potassium are macronutrients which significantly affect onion production. Nitrogen and phosphorous fertilization significantly affect growth, yield and quality of onion. The requirement of mineral fertilizer varies from place to place, depending on different factors in the growing areas. Effective use of $\mathrm{N}, \mathrm{P}$ and $\mathrm{K}$ fertilizer depends on soil condition, irrigation system, climatic factors and management factors. In all different research reports, it is described that onion is a heavy feeder for $\mathrm{N}, \mathrm{P}, \mathrm{K}$ and the application of these mineral elements enhance production significantly. The quality of onion, physiology and production is highly limited by fertilization of $\mathrm{N}, \mathrm{P}$ and $\mathrm{K}$ fertilizers. Therefore, in this review the effect of mineral nutrition on growth, physiology and yield of onion are discussed and examined in detail.
\end{abstract}

Key Words: Onion, Nitrogen, Phosphorous, Fertilization, Yield, Quality.

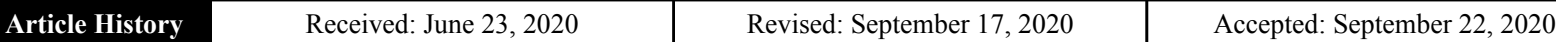

\section{INTRODUCTION}

Allium crops and their relatives are recognized as a distinct family, the Alliaceae. According to estimations, there are about 750 species in the genus Allium, among which onion, Japanese bunching onion, leeks and garlic are the most important edible Allium crops [1]. The centre of origin of onion (Allium cepa L.) is believed to be in Afghanistan, Tajikistan and Uzbekistan, western Tien Shan and India of onion, while western Asia and the areas near the Mediterranean Sea are secondary centres of development [2].

In some parts of West Africa, green leaves are propounded, and then used to make sun-dried and fermented balls, which are used later for food seasoning [3]. The extracted distillate of onion, commonly referred as "Onion oil" is widely used in the food preparations as seasoning and flavoring for savory products [4]. In addition, onion extracts could be considered not only interesting anti-browning agents [5], but also ingredients for functional food [6].

Compounds from onion are reported to have a range of health benefits which include anti-carcenogenic properties, anti-platelet activity, antit-hrombotic activity, asthmatic and antibiotic effects [7].

In many developing countries, onions are used to heal blisters and boils. In homeopathic medicine, onion is used for

\footnotetext{
Address correspondence to this author at the Department of Horticulture, College of Agriculture and Natural Resources Sciences, Debre Berhan University, Debre Berhan, P.O. Box: 445, Ethiopia; E-mail: getchamare38@gmail.com
}

the treatment of rhinnorhea and hay fever [8]. Onion is cultivated in more than 130 countries across the world. The world annual production of onion in the year 2017 was $97,862,928$ tons of dry bulbs from 5,201,591 hectares of land with an average yield $18.8 \mathrm{t} \mathrm{ha}^{-1}$. China is the top ranked producer of onion followed by countries like India, USA, Iran, Egypt, Russia and Turkey [9].

Onions are very sensitive to scarcity of nutrients than most vegetables because of their shallow and unbranched root characteristics; hence they mostly respond well to added fertilizers [10]. Nitrogen $(\mathrm{N})$, Potassium $(\mathrm{K})$, and phosphorus $(\mathrm{P})$ are referred as primary macronutrients because of the large quantities taken up by plants from the soil relative to other essential nutrients. Most crops have a higher probability of being deficient in the availability of these nutrients [11].

Nitrogen is the main building block in cells as it accounts $7 \%$ of the total dry matter of most plants [12]. Since it is present in soil, air and water in different forms, it is very complex kind of mineral nutrient. Due to this problem, it is often difficult to give a conclusive recommendation about its dose and requirement [13]. Plants require nitrogen that might be attained from a combined supply of soil and fertilizer to ensure the required amount [14]. From mineral nutrients, Phosphorus scarcity is one of the most serious problems to onion cultivation in areas, owing to low availability and high $\mathrm{P}$ immobilization in soils [15].

In this regard, response to added $\mathrm{P}$ in such kind of areas is higher than others. As reported by researches impact of 
phosphorus is mainly on the root zone of the plant, in which restricted growth is exhibited. Potassium fertilizer also affects the growth, quality, and yield of onion. In view of the above, this review is done with the objective of: to review and examine effect of phosphorus and nitrogen fertilizers on physiology, yield and yield components onion.

\section{EFFECT OF N AND P ON ONION}

\subsection{The Role of Nitrogen in Onion}

The applied Nitrogen is observed as being the main component part in tissues of plants than other mineral nutrients. Nitrogen is a major component of many essential compounds that are building block in crops. Nitrogen is needed to form chlorophyll, proteins and it is one of the main components in amino acids and other compounds important for growth, photosynthesis and metabolism. A good supply of nitrogen stimulates root growth and development as well as the uptake of other nutrients [15].

Onion is a shallow rooted plant which is the cause for high $\mathrm{N}$ requirement. But high $\mathrm{N}$ causes accelerated growth, increased days maturity, higher susceptibility to pest, lower amount of dry matter, short days of storage and thus, result in low yield and quality onion $[16,17]$. Similarly, in soils with a lower level of $\mathrm{N}$, stunting, and lower yield quality of bulb is exhibited. Therefore, lower levels of $\mathrm{N}$ in the soil negates yield, quality and shelf life of onions [18].

The amount of $\mathrm{N}$ applied to onion crop is variable from area to area and varieties. High yielding varieties usually require more $\mathrm{N}$ than low yielding ones. Results from different climatic regions of the world also show varying responses of onions to applied $\mathrm{N}[19,20]$. In some areas, for increased yield and quality of production, higher rates of nitrogen are required, but larger amount of nitrogen exists in the soil after harvesting. According to the report by Visser [21] nearly $50 \%$ of the $120 \mathrm{~kg} \mathrm{ha}^{-1} \mathrm{~N}$ commonly applied to onion fields was filtered out of the soil.

Variability in yield and quality by different nitrogen sources was investigated in different studies. One study reported that fresh and dry weights were higher by adding $\mathrm{NO}_{3}^{-}$ than $\mathrm{NH}_{4}$ and urea [22]. It is also reported that early fertilization of ammonium phosphate enhanced growth and yield of onion than ammonium nitrate [23]. This is different from the reports indicating that post-seeding addition of diammonium phosphate did not enhance the performance of transplants [24]. These variabilities could be by differences in cultural practices between direct seeding and transplanting. It was also reported that nitrogen is a limiting factor in the quality production of onions. Increased level of nitrogen in onions has resulted in better pungency than by lower levels [25, 26].

Nitrogen fertilization also helps in resistance against drought stress. This is due to its impact on adequate use of the available water in the soil. But, as leaching of nitrogen to the soil may increase water pollution therefore, applying optimum amount of nitrogen at the required time is mandatory [27, 28].

\subsection{Role of Phosphorus in Onion}

Phosphorus $(\mathrm{P})$ is reported as the second most valuable mineral nutrient which has a significant effect on onion production [29]. Several physiological and biochemical processes in plants are affected by phosphorous, being an essential part of plant and constituent of adenosine di phosphate (ADP), adenosine triple phosphate (ATP), nucleic acid, phospholipids and phosphates. Phosphorus plays a major role in transfers of energy, plant maturity, fruiting and seed development [30].

Phosphorus is one of major mineral elements, it plays part in regulating many physiological processes in the plant, which in turn will alter onion yield. One fact must be put in mind is that, the provided $\mathrm{P}$ to the plant or the soil depends largely on the available reservation of this element in the soil, so the negative or the positive results may be due to sources stored in the soil. The availability of phosphorus in soil enhances plant growth and developmental processes. It is known that $\mathrm{P}$ is a major building material of DNA molecules [31]. In addition, $\mathrm{P}$ in soil existed in two forms as organic and inorganic. Organic $\mathrm{P}$ is the most stable form than inorganic P. Due to this, inorganic phosphorus is highly taken and utilized by crops if not fixed by soil [32].

The plants take up $\mathrm{P}$ in small amounts than $\mathrm{N}$ or potassium [13]. It has attracted a tremendous amount of research effort over the last century, but its behavior in the soil and availability to crops are still imperfectly understood. One reason could be that numerous inorganic forms of $\mathrm{P}$ in soils and the wide variation in behavior between soil types. There is a major difference between crops in their ability to take up different forms of phosphate. Deficient level of $\mathrm{P}$ is one of the major limiting factors in onion production in tropical areas, due to small availability and huge amount of fixation in soils [14]. This is because of essentiality characteristics of this mineral element for root growth and if the availability is deficient, plant growth is heavily limited. Phosphorous is less mobile and the use is mainly dependent on concentration gradient and diffusions in soil root zone [33].

In onions, scarcity of mineral element, mainly $P$, is reported in reducing plant growth, size of bulbs, marketable bulb yield and delays days to maturity [34]. Soils that have a moderate level of $\mathrm{P}$, added $\mathrm{P}$ enhances growth, development and yield. Research reports on long-term fertilizer trials on loamy soils indicated that there is a strong response of onions to $P$ fertilizers in the range 0 to $52 \mathrm{~kg} \mathrm{ha}^{-1} \mathrm{P}$ [35].

\subsection{Role of Nitrogen and Phosphorous on Growth and Physiology of Onion}

Higher $\mathrm{N}$ application generally increases growth, development and physiological parameters in onion plant. According to research, the enhanced growth could be due to its direct role as building substances in the synthesis of amino acids. They combine and form proteins to aid metabolism. It is stated that $\mathrm{N}$ is a building block of plant cell components and it plays a major role in the tissues of the plants. No other mineral is able to create an effect in promoting vigorous plants. Hence the increase in plant height due to mineral nitrogen could be by its effect on cell build-up [12,36]. 
Table 1. Effects of $N$ and $P$ on plant height, number of leaves, leaf length and diameter of onion

\begin{tabular}{|c|c|c|c|c|}
\hline Nitrogen $\left(\mathrm{Kg} \mathrm{ha}^{-1}\right)$ & Plant Height (cm) & Leaves per Plant & Leaf Length (cm) & Leaf Diameter $(\mathrm{cm})$ \\
\hline 0 & $51.55 \mathrm{~b}$ & $13.42 b$ & $42.75 b$ & $0.75 \mathrm{a}$ \\
\hline 69 & $56.89 \mathrm{a}$ & $14.19 b$ & $47.67 \mathrm{a}$ & $0.77 \mathrm{a}$ \\
\hline 92 & $56.52 \mathrm{a}$ & $14.54 \mathrm{a}$ & $47.59 \mathrm{a}$ & $0.79 \mathrm{a}$ \\
\hline 115 & $56.87 \mathrm{a}$ & $14.57 \mathrm{a}$ & $48.41 \mathrm{a}$ & $0.78 \mathrm{a}$ \\
\hline 138 & $57.65 \mathrm{a}$ & $14.64 \mathrm{a}$ & $48.83 \mathrm{a}$ & $0.77 \mathrm{a}$ \\
\hline F-test & $*$ & * & $*$ & NS \\
\hline \multicolumn{5}{|c|}{ Phosphorus (Kg ha-1) } \\
\hline 0 & $56.37 \mathrm{a}$ & $14.43 \mathrm{a}$ & $47.42 \mathrm{a}$ & $0.74 \mathrm{a}$ \\
\hline 10 & $55.91 \mathrm{a}$ & $14.06 \mathrm{a}$ & $47.27 \mathrm{a}$ & $0.77 \mathrm{a}$ \\
\hline 20 & $56.01 \mathrm{a}$ & $14.29 \mathrm{a}$ & $47.13 \mathrm{a}$ & $0.79 \mathrm{a}$ \\
\hline 30 & $55.39 \mathrm{a}$ & $14.07 \mathrm{a}$ & $46.63 \mathrm{a}$ & $0.75 \mathrm{a}$ \\
\hline 40 & $55.81 \mathrm{a}$ & $14.24 \mathrm{a}$ & $46.80 \mathrm{a}$ & $0.81 \mathrm{a}$ \\
\hline F-test & NS & NS & NS & NS \\
\hline $\operatorname{SEM}( \pm)$ & 2.22 & 0.64 & 1.99 & 0.05 \\
\hline
\end{tabular}

NS and *: non significant at $\mathrm{P}<0.05$, significant at $\mathrm{P}>0.05$, respectively. SEM: Standard error of the mean. Means with the same treatment and column sharing the same letters are not significantly different at $\mathrm{P}<0.05$.

Source: Abdissa et al., (2011)

Nitrogen carbohydrate accumulation and which is governed by availability of nutrients. This could enhance stem length and vegetative growths expressed in the increase of plant height. But, an increase in amount of nitrogen increases plant height up to a certain limit in which the increase stops. As for research reports, an increase of plant height can reach up $10 \%$ with an increase of nitrogen levels from zero to higher level $69 \mathrm{~kg} \mathrm{~N} \mathrm{ha}^{-1}$ (Table 1) [37].

Other reports stated that the increase of the level of nitrogen fertilization to the highest amount of fertilization, $120 \mathrm{~kg} \mathrm{~N} \mathrm{ha}^{-1}$ increases plant height up to $58.4 \mathrm{~cm}$, but on the contrary increase of nitrogen from $40-80 \mathrm{~kg} \mathrm{~N} \mathrm{ha}^{-1}$ no significant difference was recorded [38]. Due to the heavy feeder characteristics of onion, in some studies, there is no increase in growth parameters by the application of lower levels of NPK. But, an increase in the level of nitrogen increases the growth parameters in onion. From growth parameters highest plant height is due to fertilization of higher level of nitrogen $\left(120,180,240 \mathrm{~kg} \mathrm{~N}^{-1}[36,39,40]\right.$. The need for a higher level of nitrogen could be attributed to the heavy feeder characteristics, the shallow root system and the soil condition of the growing areas.

Leaf number is one of the growth characteristics which could be significantly affected by nitrogen fertilization. Application of NPK fertilization showed significant variation in its impact on the number of leaves. The increase in the number of leaves by applying NPK fertilizer is categorized by the impact of these minerals in the building different components of proteins required for leaf development. The rate at which maximum leaf number is recorded is variable from place to place and across growing conditions. In some areas 92 $\mathrm{kg} \mathrm{N} \mathrm{ha}^{-1}$ is high amount in which the higher number of leaves is recorded (Table 1) [37]. Some other reports also indicated that a higher level of fertilizer, $120 \mathrm{~kg} \mathrm{~N} \mathrm{ha}^{-1}$ showed higher number of leaves [41]. Accordingly, a further increase to 150 $\mathrm{kg} \mathrm{N} \mathrm{ha}^{-1}$ is recommended to record larger leaf numbers [42]. Similarly, the reports on the effect of Phosphorus on onion are variable. Some reported that phosphorous fertilization increases plant growth and development $[10,36]$. On the contrary, others reported that phosphorus does not show significant effect on plant height [37]. But recent study supported that phosphorous fertilization has a significant effect on growth parameters of onion [43].

Leaf characteristics of onion are significantly affected by mineral fertilizations which could be attributed by the role of $\mathrm{N}$ on chlorophyll, enzymes and proteins synthesis. As indicated in Table 1, $\mathrm{N}$ fertilization significantly increased leaf length, but also leaf diameter. Although the onion plant did not respond to further increase, application of $69 \mathrm{~kg} \mathrm{~N}$ ha-1 increased leaf length $(47.67 \mathrm{~cm})$ by about $11.5 \%$ as compared to the control $(42.75 \mathrm{~cm})$. The report also verified that phosphorous doesn't affect leaf length and leaf diameter of onion [37]. But, the reports on the impact of $\mathrm{N}$ and $\mathrm{P}$ on leaf length and diameter are not conclusive enough. Some reports indicated that both $\mathrm{N}$ and $\mathrm{P}$ fertilizers don't have significant impact on leaf length and diameter [36]. Whereas, other reports indicated that nitrogen fertilizer has a significant impact, but if applied in higher level $200 \mathrm{~kg} \mathrm{ha}^{-1}$ [44]. This variation could be due to varietal differences and the production environment and soil conditions.

Nitrogen is one of the mineral elements which is the main constituent of fundamental cell components. It plays a vital role in tissue development of plants at a rate which other mineral elements can't do proportionally. Reports also supported that nitrogen is an essential element in build-up of protoplasm and proteins, which induce cell division and meristematic activities. In adequate supply of Nitrogen, physiological processes exhibited marked increase which can be quantified by vegetative growth factors $[45,46]$.

Phosphorus fertilization enhances many physiological processes which involve inn production of cell components, notably nucleic acid, and phospholipids. It was also reported to induce physiological activities in plants; mainly in energy metabolism and hydrolysis of phosphate and various organic 
phosphate bonds. This impact is mainly visible in onion plant by enhanced growth, and yield due to the addition of Phosphorous [47, 48]

\subsection{Effects of Nitrogen and Phosphorous on Bulb Characteristics of Onion}

\subsubsection{Neck Thickness and Split Bulbs}

Neck-thickness is a physiological disorder mainly influenced by season, site and cultivar, not by mineral nutrients [16]. A report by Jilani [44] indicated that $\mathrm{N}$ at rate of 200 $\mathrm{kg} / \mathrm{ha}$ increased the number of thick-necked bulbs and assumed as one of the good qualities of onion. Similarly, Abdissa et al. [37] explained that NP fertilization didn't affect the formation of thick-necked bulbs, but increased bulb split in onion. Bulb splitting is also reported to be controlled genetically, in which shallots being extremely affected [49].

The increasing rate of nitrogen resulted in a greater number of thick naked bulbs than the lower levels of nitrogen [50]. Thick-nakedness in bulbs mainly occurred when the bulbs fail to complete normal bulb formation processes in which continuous leaf growth existed [51]. The continuous vegetative growth could be due to increased nitrogen fertilization, which enhances more cell division and thus results in continued growth leaves that keep the neck wide. Similarly, observed significant effect of nitrogen on neck thickness but not by phosphorus. Neck thickness is the factor which indicates the storability ability of onion. Onion with thick neck diameter shows less storability than thick necks. Accordingly, the higher the level of nitrogen, the higher the neck thickness. This causes less storability onions which are fertilized with higher rates of nitrogen $[20,38]$.

\subsubsection{Bulb Diameter and Length}

Bulb diameter and length is variable from verity to variety of onion and their response to NPK fertilization. The combination of optimum fertilization of NPK in different verities increases in bulb diameter of the onion [52]. Some reports magnify the impact of nitrogen on increasing bulb diameter than phosphorous and nitrogen fertilization. The impact of phosphorous on increasing bulb diameter and length and its direct impact on enhancing bulb characteristics is restricted than nitrogen [36, 53, 54].

The amount of nitrogen fertilizer for large diameter of bulbs and longer bulb height is variable. It depends on the condition of the soil and the management systems in the growing areas. In some areas, the range of nitrogen fertilization which was considered as optimum for larger bulb is between 120 to $150 \mathrm{~kg} \mathrm{~N} \mathrm{ha}^{-1}[54,55]$. The impact of nitrogen on bulb diameter and length may be linked to the increase in dry matter production, its allocation to the bulb and to the role of phosphorus on partitioning assimilates to bulb development $[56,57]$.

Effect of NPK fertilizer on bulb diameter and length is reported to be affected by the level of irrigation water supply. Highest irrigation water with highest fertilization interacted in an increase of bulb diameter and length. In reverse, high level of fertilization of NPK with lower irrigation frequency and water level increases the amount of volatilization and loss of the fertilizers. This situation causes lower impact of NPK on bulb diameter and length [58].

\subsection{Yield and Yield Related Characteristics}

\subsubsection{Bulb Dry Weight}

Nitrogen acts as a building block for production of carbohydrates, amino acids, nucleic acids and chlorophylls. Nitrogen fertilization to the optimum level enhances the production of these substances thereby enhancing the bulb yield of onion. Bulb dry weight increases with an increase in nitrogen fertilization [59]. This is observed in an increase of 50 $\mathrm{kg} \mathrm{N} \mathrm{ha}^{-1}$ as yield of onion showed dramatic increase to 7.00, 22.51 and 27.40 percent from zero level of application [60]. Increasing the level of nitrogen from zero to the optimum level shows progressive increases in the bulb dry weight of onion. But further increase from that optimum level depresses down in quantity of bulb dry weight due to the toxicity impact of the fertilizer [55, 61, 62].

Phosphorous also enhances the plant growth and development of plants by its influential impact for components like nucleic acids and phospholipds. This is reflected on onion by increasing the bulb dry weight [63, 64]. According to Morsey et al. [65], increasing the $\mathrm{P}$ dose for onion fertilization from 16 units of $\mathrm{P}_{2} \mathrm{O}_{5}$ up to 48 units/fed recorded in an increase of bulb yield. It indicated that the heaviest tonnage of bulbs yield of 10.72 and 15.72 tons/fed respectively for 1 and 2 seasons were observed on plants which supplied the highest $\mathrm{P}$ rate of 48 units of $\mathrm{P}_{2} \mathrm{O}_{5} /$ fed. This could be due to the major influence of mineral $\mathrm{P}$ on the productivity of onion plant, hence enhanced amount of total bulb yield [64].

\subsubsection{Mean Bulb Weight}

Bulb weight of onion directly and positively correlated with plant height, leaf number, length of leaves and days to maturity and bulb size. Plant growth and yield parameters are also affected by fertilizing $\mathrm{N}$ and $\mathrm{P}$ during the growing period $[15,60,64]$.

On the other hand, some other reports indicated as phosphorous fertilization does not significantly increase the mean bulb weight. But El-hamady [66] reported that Nitrogen and phosphorus fertilization significantly affected onion Bulb weight (Table 2). This report described an escalating level of $\mathrm{N}$ from $72 \mathrm{~kg} \mathrm{~N}^{-1}$ to $216 \mathrm{~kg} \mathrm{~N} \mathrm{ha}^{-1}$ increases the bulb yield of onion to 151.59 and $152.43 \mathrm{~g}$ in $2013 / 14$ and 2014/15 year, respectively. Similarly, the mean bulb weight of onion increases significantly when the rate of phosphorous increases from $37 \mathrm{~kg} \mathrm{P}_{2} \mathrm{O}_{5}$ ha $^{-1}$ to $148 \mathrm{~kg} \mathrm{P}_{2} \mathrm{O}_{5} \mathrm{ha}^{-1}$.

Accordingly, Abdissa et al. [37] reported that bulb weight of onion responds positively to added nitrogen. Mean bulb weight was enhanced by about $26 \%$ in by rate of $69 \mathrm{~kg} \mathrm{~N}^{-1}$ as compared to zero fertilizer application; although higher rate of $\mathrm{N}$ did not enhance bulb weight (Table 1). 
Table 2. Response of onion to nitrogen and phosphorus fertilizer rates during 2014/2015 and 2015/2016 seasons.

\begin{tabular}{|c|c|c|c|c|c|c|c|c|c|c|}
\hline \multirow[t]{2}{*}{ Treatments } & \multicolumn{2}{|c|}{ Bulb Length (cm) } & \multicolumn{2}{|c|}{ Bulb Weight (g) } & \multicolumn{2}{|c|}{ Total Fresh Bulb Yield t/ha } & \multicolumn{2}{|c|}{ Marketable Yield t/ha } & \multicolumn{2}{|c|}{ T.S.S\% } \\
\hline & $2013 / 2014$ & $2014 / 2015$ & $2013 / 2014$ & $2014 / 2015$ & $2013 / 2014$ & $2014 / 2015$ & $2013 / 2014$ & $2014 / 2015$ & $2013 / 2014$ & $2014 / 2015$ \\
\hline \multicolumn{11}{|c|}{$\mathrm{kg} \mathrm{N} \mathrm{ha}^{-1}$} \\
\hline $72 \mathrm{~kg} \mathrm{~N} \mathrm{ha}^{-1}$ & 4.95 & 5.00 & 138.31 & 139.15 & 35.320 & 35.700 & 28.740 & 28.939 & 10.87 & 10.96 \\
\hline $120 \mathrm{~kg} \mathrm{~N} \mathrm{ha}^{-1}$ & 5.30 & 5.33 & 139.75 & 140.68 & 37.480 & 37.500 & 29.880 & 29.981 & 11.12 & 11.22 \\
\hline $168 \mathrm{~kg} \mathrm{~N} \mathrm{ha}^{-1}$ & 5.47 & 5.57 & 143.95 & 144.77 & 38.400 & 38.599 & 30.761 & 31.001 & 11.33 & 11.44 \\
\hline $216 \mathrm{~kg} \mathrm{~N} \mathrm{ha}^{-1}$ & 5.54 & 5.67 & 151.59 & 152.43 & 39.520 & 39.600 & 31.980 & 32.201 & 11.61 & 11.70 \\
\hline F-test & $*$ & $*$ & $*$ & $*$ & $*$ & $*$ & $*$ & $*$ & $*$ & $*$ \\
\hline L.S.D. $5 \%$ & 0.11 & 0.11 & 0.45 & 0.29 & 0.326 & 0.330 & 0.362 & 0.276 & 0.03 & 0.03 \\
\hline \multicolumn{11}{|c|}{$\mathrm{kg} \mathrm{P}_{2} \mathrm{O}_{5} \mathrm{ha}^{-1}$} \\
\hline $37 \mathrm{~kg} \mathrm{P}_{2} \mathrm{O}_{5} \mathrm{ha}^{-1}$ & 5.22 & 5.31 & 141.15 & 142.02 & 37.241 & 37.382 & 29.861 & 30.101 & 11.13 & 11.22 \\
\hline $74 \mathrm{~kg} \mathrm{P}_{2} \mathrm{O}_{5} \mathrm{ha}^{-1}$ & 5.26 & 5.35 & 142.95 & 143.78 & 37.519 & 37.620 & 30.130 & 30.444 & 11.19 & 11.29 \\
\hline $111 \mathrm{~kg} \mathrm{P}_{2} \mathrm{O}_{5} \mathrm{ha}^{-1}$ & 5.37 & 5.44 & 144.33 & 145.19 & 37.960 & 38.081 & 30.499 & 30.619 & 11.27 & 11.37 \\
\hline $148 \mathrm{~kg} \mathrm{P}_{2} \mathrm{O}_{5} \mathrm{ha}^{-1}$ & 5.43 & 5.52 & 145.20 & 146.93 & 38.261 & 38.340 & 30.900 & 31.020 & 11.34 & 11.43 \\
\hline F-test & $*$ & $*$ & $*$ & $*$ & $*$ & $*$ & $*$ & $*$ & $*$ & $*$ \\
\hline L.S.D. $5 \%$ & 0.06 & 0.05 & 0.28 & 0.28 & 0.149 & 0.149 & 0.185 & 0.175 & 0.02 & 0.02 \\
\hline F-test & N.S. & N.S. & * & * & N.S. & N.S. & N.S. & N.S. & N.S. & N.S. \\
\hline
\end{tabular}

N. S. $=$ Not significant, $*=$ significant at $5 \%$

Source: M. M. El-hamady (2017)

\subsubsection{Total and Marketable Yield}

Total bulb yield and marketable yield are the main economic parts of onion plant. The fertilizer rate which give higher amount of these parameters, is considered as optimum and recommended for onion production. But, the main problem in fertilizer rates is the need to cooperate between fertilizer cost and economic return by the onion marketable yield. Even if the yield is higher by adding a high level of NP fertilization if the cost benefit ratio shows negative it is not recommended for farmers [43, 67].

In some reports, the amount of $\mathrm{N}$ required to produce a higher amount $t$ of marketable bulb yield is as low as $60 \mathrm{~kg} \mathrm{~N}$ $\mathrm{ha}^{-1}$ [68]. But others reported as a very high amount of nitrogen fertilization, $250 \mathrm{~kg} \mathrm{~N}^{-1}$ is required to produce higher marketable and total bulb yields [64, 69]. This could be due to variations in variety, soil and management conditions. But the report by Nasreen et al. [55], seems conclusive enough for all other reports. The researchers indicated that the increase in nitrogen fertilization from zero to $120 \mathrm{~kg} \mathrm{~N}^{-{ }^{-1}}$ levels shows further increase in marketable yield of onion until it stops at increase stops at the highest rate which is $160 \mathrm{~kg} \mathrm{~N} \mathrm{ha}^{-1}$. These trends indicate an increased photosynthetic area by addition of $\mathrm{N}$ which hugely acts to improve onion productivity through the formation of higher assimilates.

On the other hand, Boyhan and Torrance [70], showed that with an increase of nitrogen fertilizer from control to $250 \mathrm{~kg} \mathrm{~N}$ $\mathrm{ha}^{-1}$ the yield of onion increases dramatically and there was significant treatment $\times$ year interaction (Fig. 1). In contrast to nitrogen, as the rate of phosphorous increases from zero to 147 $\mathrm{P}_{2} \mathrm{O}_{5} \mathrm{ha}^{-1}$ the effect of phosphorus $\mathrm{P}$ fertilizer rates did not onion bulb yield (Fig. 2).

In contrast to Boyhan and Torrance [70] report, many investigators reported, addition of $\mathrm{P}$ fertilizer enhances productivity of onion, hence increases marketable and unmarketable bub yield. It may be attributed to the enhancement of phosphorus on the plant growth and it's reflected on the bulbs yield. This agrees with other researchers, which indicated increased bulb yield due to P application [63, 71].

Accordingly, Tekeste et al. [56] observed highest total bulb yield by rate of $103.5 \mathrm{~kg} \mathrm{~N}$ ha- 1 and $138 \mathrm{~kg} \mathrm{P}_{2} \mathrm{O}_{5} \mathrm{ha}^{-1}$. In this report, the maximum bulb yield obtained by this combined rate is above the minimum total bulb yield obtained at control (zero) application of the two fertilizers by about $53 \%$.

\subsection{Impact of $N$ and $P$ on Quality of Onion}

The effect of Nitrogen is quantified on average and observed that dry matter percentage of $13 \%$ has been reported with a variation from 11 to $14 \%$ in shallot [72]. They found that similar to other crops, increasing the rate of $\mathrm{N}$ resulted in an increased percentage of $\mathrm{N}$ in dry bulbs while percentage of minerals didn't change. However, increasing the $\mathrm{N}$ rate beyond $200 \mathrm{~kg} \mathrm{~N} \mathrm{ha}^{-1}$ decreased dry matter percentage in bulbs. Randle and Ketter [73] mentioned onion pungency develops when the enzyme alliinase hydrolyses the flavor precursors S-alk(en)yl cystein sulfoxides in tissue maceration. Within intact cells the enzyme alliinase is classified in the cell vacuole and flavor precursors exist in cytoplasm.

A reaction, therefore, only happens when onion tissues are damaged and the enzyme and substrate are combined together as organelles are disrupted. The reaction products are pyruvate, ammonia and the many volatile sulfur compounds characteristic of onion and shallot flavor and aroma [74]. It was also reported that pyruvic acid content is highly related to degree of onion pungency [75]. Pyruvic acid contents found a variable between 1 and 18 micromoles for different onion cultivars. Low pungency ( 0 to 3 micromoles pyruvic acid per gram fresh onion), medium pungency ( 3 to 7 micromoles 
pyruvic acid per gram fresh onion) and high pungency (above 7 micromoles pyruvic acid per gram fresh onion) were used as a guide to pungency strength by the Sweet Onion industry in Georgia, USA [75].

Mineral $\mathrm{N}$ fertilization was found to alter both flavor, intensity and quality of onion [76]. While $\mathrm{N}$ levels varied from 0.22 to $0.97 \mathrm{~g} \mathrm{~L}^{-1}$ in hydroponic solutions, enzymatically formed pyruvate was enhanced linearly and decreased at highest $\mathrm{N}$ rates. With an increase of $\mathrm{N}$ rates, MCSO ((+)-Smethyl-L-cysteine sulphoxide), accordingly, 1-PECO 19 (trans-(+)-S-(1-propenyl)-L-cysteine sulphoxide) showed initial increase but then decreased with an increase in $\mathrm{N}$ rates. It is observed that PECO generally increased with an increase in $\mathrm{N}$ rates. It was known that changes in the ACSO (S-
alk(en)yl-L-cysteine sulphoxide) concentrations and ratios affected sensory perceptions in onion flavor [25].

Only little information is available on $\mathrm{P}$ effects on quality attributes of onion. Woldetsadik [76] stated that on shallot (Allium ascalonicum) crop, application of $\mathrm{P}$ slightly increased number of soluble solids, dry matter percentage and pyruvate content of bulbs.

Onion mineral constituents mainly total nitrogen content of bulbs and sulphur content of bulbs were reported to be significantly influenced by Nitrogen fertilization. Increasing the level of $\mathrm{N}$ fertilizer increases the content of these minerals. Mineral constituents like Boron, Calcium and Magnesium also showed marked decrease due to increased application of $\mathrm{N}$ [25].

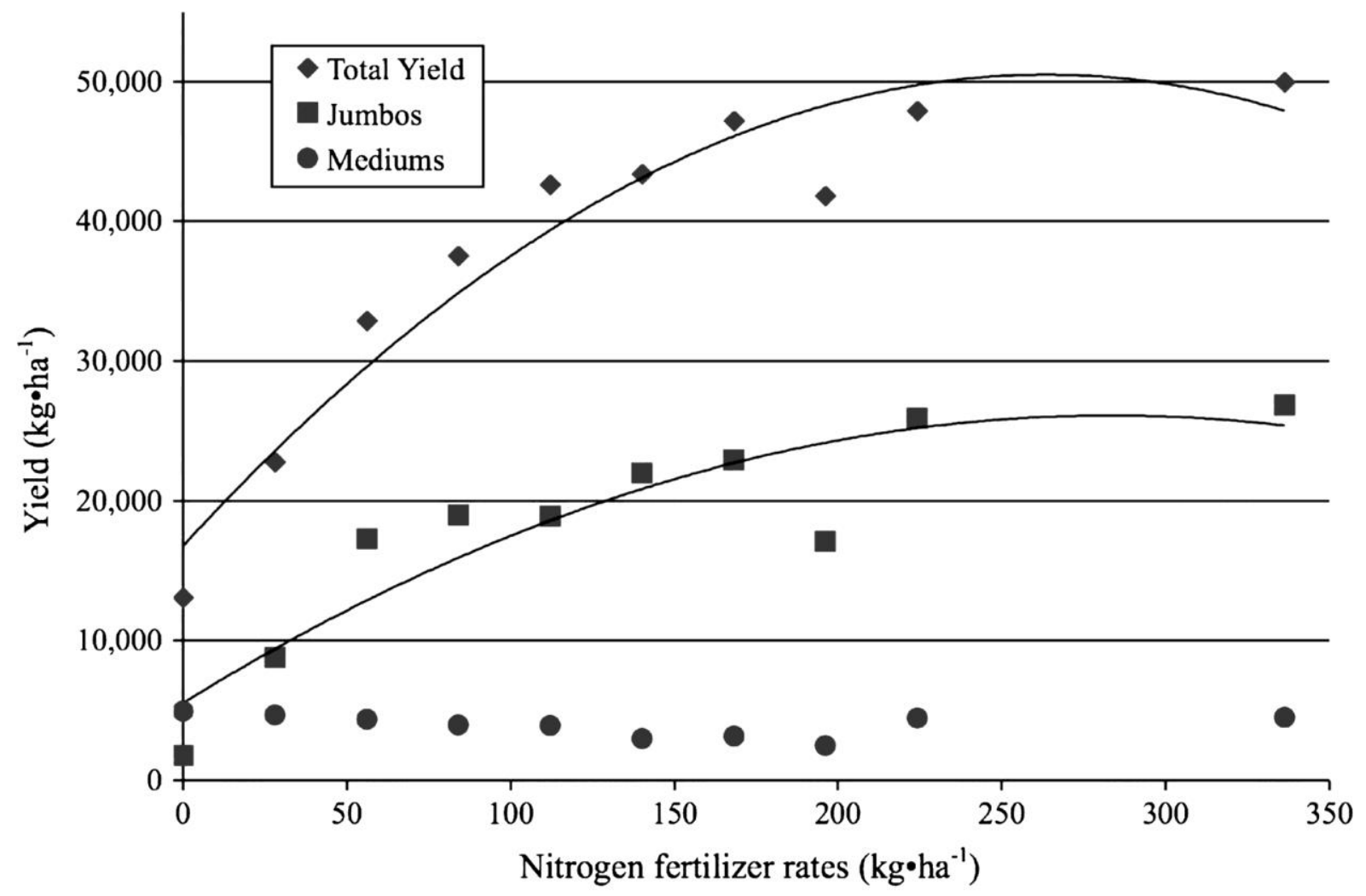

Jumbos $\geq 7.6 \mathrm{~cm}$, Mediums $\geq 5.1$ and $<7.6 \mathrm{~cm}$.

\begin{tabular}{lccc} 
& \multicolumn{3}{c}{ Probabilities } \\
\cline { 2 - 4 } & Total yield & Jumbos & Mediums \\
\hline Treatment & 0.000 & 0.000 & 0.940 \\
Year & 0.000 & 0.000 & 0.000 \\
Treatment x Year & 0.000 & 0.009 & 0.000 \\
Linear & 0.000 & 0.000 & \\
Quadratic & 0.000 & 0.000 & \\
\hline $\mathrm{R}^{2}$ & 0.926 & 0.817 & \\
\hline
\end{tabular}

Fig. (1). Impact of Nitrogen fertilization on onion yield.

Source: Boyhan et al. 2002 


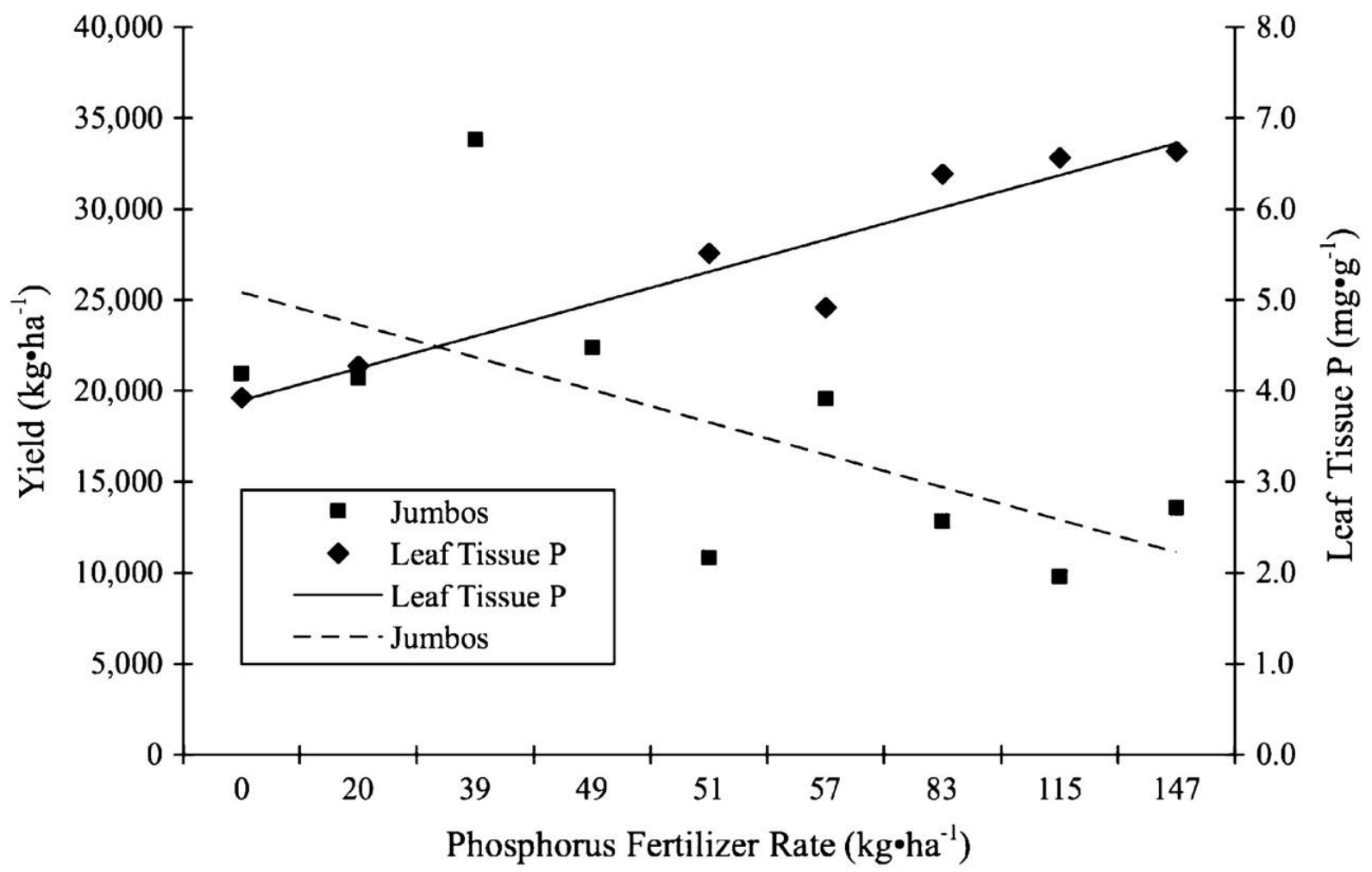

Jumbos $\geq 7.6 \mathrm{~cm}$

\begin{tabular}{lcccccccc} 
& \multicolumn{8}{c}{ Probabilities } \\
\cline { 2 - 9 } & $\begin{array}{l}\text { Total } \\
\text { yield }\end{array}$ & Jumbos & Mediums & $\mathrm{N}$ & $\mathrm{P}$ & $\mathrm{K}$ & $\mathrm{Ca}$ & $\mathrm{S}$ \\
\hline Treatment & 0.069 & 0.001 & 0.118 & 0.098 & 0.038 & 0.434 & 0.412 & 0.201 \\
Year & 0.000 & 0.000 & 0.014 & 0.402 & 0.002 & 0.025 & 0.053 & 0.001 \\
Treatment x Year & 0.666 & 0.914 & 0.794 & 0.668 & 0.121 & 0.698 & 0.824 & 0.200 \\
Linear & & 0.000 & & & 0.000 & & & \\
Quadratic & & 0.873 & & & 0.284 & & & \\
\hline $\mathrm{R}^{2}$ & & 0.322 & \multicolumn{1}{c}{0.879} & & & \\
\hline
\end{tabular}

Fig. (2). Yield response of Onion to phosphorus application.

Source: Boyhan et al. 2002

An increase in fertilization of $\mathrm{N}$ in onions recorded increased mineral constituents Calcium and potassium. An increase from zero level of $\mathrm{N}$ to higher rates significantly increase the content of these mineral elements. But, a very high level of $\mathrm{N}$ created a reduction in $\mathrm{Ca}$ content in onion bulbs. This could be a factor of higher concentration, which negates the impact of $\mathrm{N}$ on onion bulb [25, 77]. Supply of the phosphorus fertilizer in the chemical form and bio-fertilizer also reported increased on the level protein, N, P and K as well as TSS of onion plants [78].

\subsection{Role of $\mathrm{K}$ in Onion Plant}

Potassium is one of the macro mineral nutrients which affect onion plant growth, development, yield and quality. It is one of the most highly available minerals in most soils. Plants utilize the water soluble and exchangeable forms of potassium than other forms. In the soil the three forms of potassium present are exchangeable form (very small), unavailable form
(90-98\%), the slowly available from (1-10\%) and readily available form (1-2\%). The amount of available potassium must always be high enough to satisfy peak requirements if maximum crop yields are aimed at. However, maximum uses of the potassium reserves, the low flux rate of potassium from these reserves could sometimes limit yield [25, 79 - 83].

It has substantial impact energy systems, translocation and storage of plant assimilates, water potential in side cell of plants, and storage of assimilates [84, 85]. The main processes of plants are including photosynthesis, protein synthesis and enzyme activities [86].

Bulb formation and storage are factors which are mainly influenced by $\mathrm{K}$ fertilization. In adequate $\mathrm{K}$ fertilization the formation of bulb is positively influenced. It also influences resistance of potato plants to certain diseases. Storage quality of bulbs is enhanced in optimum $\mathrm{K}$ fertilization. $\mathrm{K}$ deficiency in onion is expressed by the appearance of brown tips in older 
leaves and poor bulb formation $[87,88]$.

\subsection{Effect of $K$ on Growth and Physiology of Onion}

Potassium fertilization significantly affects the vegetative growth, development and physiological process of onion plant $[89,90]$. Highest plant height was observed in response to $\mathrm{K}$ fertilization of $120 \mathrm{~kg} \mathrm{~K}_{2} \mathrm{O} \mathrm{ha}{ }^{-1}$. An increase of $\mathrm{K}$ level from control to $120 \mathrm{~kg} \mathrm{ha}^{-1}$ allivates the height of plant by $7 \%$ [91]. Similar report indicated that highest height of onion plant 41 $\mathrm{cm}$, was recorded by the addition of $120 \mathrm{~kg} \mathrm{ha}^{-1}$ of $\mathrm{K}$ [92].

$\mathrm{K}$ fertilization also enhances the number of leaves, leaf diameter and leaf length of onion plant. In an experiment done by two forms of $\mathrm{K}$ fertilizers, potassium chloride and potassium nitrate, higher plant height, leaf fresh weight and dry weight were recorded by both forms of K [93]. Impact of potassium in increasing plant height and leaf diameter could be associated with its impact on physiological process mainly, photosynthesis, assimilate transport and water potential inside onion plant [94].

Other reports also indicated that plant height, number of leaves per plant and leaf length were reported to be highly influenced by application of NKS fertilization. Higher amount of those parameters was recorded while onion is fertilized by percentage ratio of $150 \% \mathrm{~N}+75 \% \mathrm{~K}_{2} \mathrm{O}+200 \% \mathrm{~S}$ [95]. The other role of $\mathrm{K}$ on vegetative growth of onion is its positive influence in uptake of other minerals $\mathrm{N}$ and $\mathrm{P}$. Therefore, in addition to its direct impact on plant growth and development, it also affects by its indirect influence in the uptake of other minerals $[84,86]$.

In reports by other researchers, maximum plant height of $41.8 \mathrm{~cm}$ and the largest number of leaves per plant was recorded by $\mathrm{K}$ fertilization at a rate of $175 \mathrm{~kg} \mathrm{~K} \mathrm{ha}^{-1}$ [96]. Reports verified that an increase in onion plant growth due to $\mathrm{K}$ fertilization is by its impact in physiological processes like photosynthesis, assimilate transport, and water potential of onion. Soils fertilized by adequate amount of $\mathrm{K}$ exhibited enhanced formation of chlorophyll, increased enzymatic activity for synthesis of protein and hasten the translocation of assimilates. It is also verified that in deficient supply of $\mathrm{K}$ onion plant is susceptible to diseases, stunting of growth and lower water use efficiency $[97,98]$.

\subsection{Effect of $K$ on Yield and Quality of Onion}

Onion yield parameters mainly, bulb length, diameter of bulb, bulb fresh weight and bulb yield per hectare are significantly affected by mineral $\mathrm{K}$ deficiency and availability $[85,88]$. In optimum supply of $\mathrm{K}$; higher diameter, length, fresh weight of bulbs and maximum yield per hectare was recorded [96, 97]. In deficient amount of $\mathrm{K}$, the yield parameters and quality of onion responded negatively [99, $100]$.

According to research reports, the highest yield parameters were recorded by addition of higher rates of $\mathrm{K}$ fertilizer and the lowest from control (zero level of K) [89, 90]. The increase in the level of $\mathrm{K}$ from control to $120 \mathrm{~kg} \mathrm{ha}^{-1}$ increases the total yield of onion by about $16 \%$. Similarly, this rate of $\mathrm{K}$ enhances marketable bulb yield by about $50 \%$ from control [91]. This could be associated with the impact of $\mathrm{K}$ in enhancing physiological processes in onion [99].

Soil application of $\mathrm{K}$ gives higher onion bulb yield and quality than foliar application. Soil application of $\mathrm{K}$ in form of $\mathrm{KNO}_{3}$ gave highest amount of total yield, bulb weight and TSS [46]. Proportional with impact of potassium on vegetative growth of onion, yield attributes mainly like neck thickness, bulb diameter, bulb length and marketable weight of bulbs are highly dependent on K fertilization. Research reports outlined that there is direct relationship between impact of $\mathrm{K}$ on vegetative growth and yield attributes [85, 92, 101, 102].

Other reports indicated that yield increment in onion due to $\mathrm{K}$ fertilization is associated with its significant impact on synthesis of carbohydrates and proteins. Higher production of such substrates impacts the production of large sized bulbs and higher marketable onions [86, 89, 97]. Quality of onion as expressed by TSS (total soluble solutes) is one of the parameters which significantly influenced by $\mathrm{K}$ fertilization. Application of $\mathrm{K}$ to the optimum level enhances the amount of TSS in onion plants [99]. Other parameters like Ascorbic acid content are also influenced by addition of $\mathrm{K}$ in which higher amount was recorded in fertilized lands than unfertilized ones [102].

Potassium fertilization in rate of $144 \mathrm{~K}_{2} \mathrm{O}$ units per fed created peak production of nutritional values in onion tissue (protein, N, P, K, Fe, Mn, $\mathrm{Zn}$ and $\mathrm{Cu}$ ) [101]. Accordingly, dry matter percentage of onion also increased by addition of $\mathrm{K}$ [90]. Increasing levels of $\mathrm{K}$ from control $120 \mathrm{~kg} \mathrm{ha}^{-1}$ encouraged bulbs to produces higher carbohydrates, protean and minerals which increase dry matter content [91].

\section{CONCLUSION}

Mineral fertilizers mainly nitrogen, potassium and phosphorous have significant a role on onion production. The effect of this mineral fertilizers is very high on plant growth, physiology, unmarketable bulb yield, total bulb yield and marketable yield of onion. From the different researches done in different parts of the world it can be concluded that:

- The amount of N, K and P added to onion varies from place to place.

- The optimum amount of fertilizer required for onion production varies from place to place. Therefore, place specific recommendation is needed

- The variations in the amount of $\mathrm{N}, \mathrm{K}$ and $\mathrm{P}$ added on onion for high productivity depends on soil condition, climatic factors, irrigation system and management systems

- According to the research, it is almost difficult to produce onion without addition of $\mathrm{N}, \mathrm{K}$ and $\mathrm{P}$

- Keeping in view of the impact of N, K and P fertilizers on soil, water and atmosphere, adequate method of application and effective use of fertilization should be devised

- As the level of application of N, K and P increases from year to year it should have to be well understood its effect on productivity of the soil and the cost of production for small scale farmers. 
Finally, for better use of $\mathrm{N}, \mathrm{K}$ and $\mathrm{P}$, the use of organic fertilizer in combination of this mineral fertilizers should be considered.

\section{CONSENT FOR PUBLICATION}

Not applicable

\section{FUNDING}

None

\section{CONFLICT OF INTEREST}

The author declare no conflict of interest, financial or otherwise.

\section{ACKNOWLEDGEMENTS}

Declared none.

\section{REFERENCES}

[1] Ranbinowitch HD, Currah L. Allium Crop Science: Recent Advances. CAB International, Wallingford, UK.: CABI publishing 2002; pp. 19-20.

[2] Malik YS, Nehra BK. Effect of steckling, planting dates and spacing on seed yield of radish (Raphanus sativus L.) cv. Pusa chetki. Vegetable Science 1999; 26(2): 149-51

[3] Grubben JH, Denton DA. Plant resources of tropical Africa PROTA Foundation, Wageningen; Back huys, Leiden. Wageningen: CTA 2004.

[4] Resemann J, Carle R. Comparative study on the interrelationship between flavour related parameters of onion cultivars (Allium Cepa L.) and their applicability to forecasting onion. Food. Agric Environ 2003; 1(3\&4): 104-11.

[5] Tinello F, Mihaylova D, Lante A. Valorization of onion extracts as anti-browning agents 2020.http://www.ijFSAB.com

[6] Tinello F, Vendramin V, Barros Divino V, et al. J Funct Foods 2017; 39: 233-7.

[http://dx.doi.org/10.1016/j.jff.2017.10.018]

[7] Griffiths G. Onions- A global benefit to health. John Wiley and Sons, Ltd. 2002.

[8] Morrison M, Roger D. Desktop guide to keynotes and confirmatory symptoms. Grass Valley, CA: Hahnemann Clinic publishing 1993.

[9] FAO (Food and Agriculture Organization). Production year book 2017.

[10] Brewster JL. Onions and other vegetable Alliums. Wallingford, UK: CAB International 1994.

[11] Marschner H. Mineral Nutrition of Higher Plants. 2nd ed. London: Academic press 1995; p. 196.

[12] Bungard RA, Wingler A, Morton JD, Andrews M. Ammonium can stimulatenitrate and nitrite reductase in the absence of nitrate in Clematis vitalba. Plant Cell Environ 1999; 22: 859-66. [http://dx.doi.org/10.1046/j.1365-3040.1999.00456.x]

[13] Archer J. Wharfedaale Road, Ipswich, Suffolle.: Farming Press Ltd. 1988.Crop Nutrition and Fertilizer Use. Second Edition.

[14] Fairhurst T, Lefroy R, Mutert E, Batijes N. The importance, distribution and causes of phosphorus deficiency as a constraint to crop production in the tropics. Agroforestry Forum 1999; 9: 2-8.

[15] Brady NC, Weil RR. The nature and properties of soils. 13th ed. Upper Saddle River, New Jersey: Prentice Hall 2002.

[16] Brewster JL. The effect of temperature on the rate of sprout growth and development within stored onion Bulbs. Ann Appl Biol 1987; 111: 463-5.

[http://dx.doi.org/10.1111/j.1744-7348.1987.tb01475.x]

[17] Sorensen JN, Grevsen K. Sprouting in bulb onions (Allium cepa L.) as influencedby nitrogen and water stress. J Hortic Sci Biotechnol 2001; 76: 501-6.

[http://dx.doi.org/10.1080/14620316.2001.11511400]

[18] Rice RP, Rice LW, Tindall HD. Fruit and vegetable production in warm climates. London, Basingstoke: The Macmillan press Ltd. 1993.

[19] Buckland K, Reeve JR, Alston D, Nischwitz C, Drost D. Effects of nitrogen fertility and crop rotation on onion growth and yield, thrips densities, iris yellow spot virus and soil properties. Agric Ecosyst
Environ 2013; 177: 63-74.

[http://dx.doi.org/10.1016/j.agee.2013.06.005]

[20] Gebretsadik K, Dechassa N. Response of onion (allium cepa l.) to nitrogen fertilizer rates and spacing under rain fed condition at tahtay koraro, ethiopia. Sci Rep 2018; 8(1): 9495.

[http://dx.doi.org/10.1038/s41598-018-27762-x] [PMID: 29934563]

[21] Visser CIM. Effect of split application of nitrogen on yield and nitrogen recovery of spring-sown onions and on residual nitrogen. J Hortic Sci Biotechnol 1998; 73: 403-11.

[http://dx.doi.org/10.1080/14620316.1998.11510992]

[22] Inal M, Sunal E, Kanbak G, Zeytinoglu S. Effects of postmenopausal hormone replacement and alpha-tocopherol on the lipid profiles and antioxidant status. Clin Chim Acta 1997; 268(1-2): 21-9. [http://dx.doi.org/10.1016/S0009-8981(97)00153-8] [PMID: 9495568]

[23] Stone DA. The effects of starter fertilizers on the growth and nitrogen use efficiency of onion and lettuce. Soil Use Manage 2000; 16: 4248. [http://dx.doi.org/10.1111/j.1475-2743.2000.tb00171.x]

[24] Boyhan George E, Reid L Torrance. Crop Reports Vidalia OnionsSweet Onion Production in Southeastern Georgia 2002; 12(2)

[25] Randle WM. Increasing nitrogen concentration in hydroponic solutions affects onion flavour and bulb quality. J Am Soc Hortic Sci 2000; 125 : 254-9.

[http://dx.doi.org/10.21273/JASHS.125.2.254]

[26] Coolong TW. Temperature, nitrogen, and sulfer fertility influence the flavor pathway in onion (Allium cepa L.) MS thesis. UnivGa, Athens. 2003.

[27] Shock CC, Feibert EBG, Saunders LD. 2004. Pungency of selected onion varieties before and after storage http://narc2002.wsu.edu

[28] Waraich EA, Saifullah AR, Ehsanullah MY. Role of mineral nutrition in al- leviation of drought stress in plants. AJCS 2011; 5: 764-77.

[29] Tisdale SL, Nelson W, Beaton L. Soil Fertility and Fertilizers. 5th ed.. New York.: Mcmillan publishing company 1995.

[30] Miller RW, Donahue RL. Soils in Our Environment. 6th ed. PrinticeHall Inc. 1995.

[31] Pant HK, Reddy KR. Potential internal loading of phosphorus in a wetland constructed in agricultural land. Water Res 2003; 37(5): 965-72.

[http://dx.doi.org/10.1016/S0043-1354(02)00474-8]

[PMID: 12553971]

32] Hinsinger P. Bioavailability of soil inorganic phosphorus in the rhizosphere as affected by root-induced chemical changes. Plant Soil 2001; 237(2): 173-95.

[http://dx.doi.org/10.1023/A:1013351617532]

[33] Mcpharilin IR, Robertson WJ. Response of onions (Allium cepa L.) to phosphate fertilizer placement and residual phoshorus on a karrakatta sand. Aust J Exp Agric 1999; 39: 351-9.

[http://dx.doi.org/10.1071/EA98145]

[34] Greenwood DJ, Stone DA, Karpinets TV. Dynamic model for the effects of soil $\mathrm{P}$ and fertilizer $\mathrm{P}$ on crop growth, $\mathrm{P}$ uptake and soil $\mathrm{P}$ in arable cropping: Experimental test of the model for field vegetables. Ann Bot (Lond) 2001; 88: 293-306.

[http://dx.doi.org/10.1006/anbo.2001.1459]

[35] Alt D, Ladebusch H, Melzer O. Long-term trial with increasing amounts of phosphorus, potassium and magnesium applied to vegetable crops. Acta Hortic 1999; (506): 29-36.

[http://dx.doi.org/10.17660/ActaHortic.1999.506.2]

[36] Rizk FA. Productivity of onion plant (Allium Cepa, L.) as affected by method of planting and NPK application. Egypt J Hortic 1997; 24(2): 219-38.

[37] Abdissa Y, Tekalign T, Pant LM. Growth, bulb yield and quality of onion (Allium cepa L.) as influenced by nitrogen and phosphorus fertilization on vertisol I. Afr J Agric Res 2011; 6(14): 3252-325.

[38] Fisseha M. Response of onion (Allium cepa var. cepa) to combined application of farmyard manure and inorganic nitrogen and phosphorous fertilizer at Alage, Ethiopia. MSc thesis. : Haramaya University, Ethiopia.2010.

[39] Maier NA, Dahlenburg AP, Twigden TK. Assessment of the nitrogen status of onions (Allium cepa L.) cv. Cream Gold by plant analysis. Aust J Exp Agric 1990; 30(6): 853.

[http://dx.doi.org/10.1071/EA9900853]

[40] - Lee-Jongatae; Ha-Injong; Iee-Changung; Moon-Jinseong and ChoYongcho. Effect of $\mathrm{N}, \mathrm{P}_{2} \mathrm{O}_{5}$ and $\mathrm{K}_{2} \mathrm{O}$ application rates and top-dressing time on growth and yield of onion (Allium cepa L.) under spring culture in low land. Korean J Hort Sci Tech 2003; 21(4): 260-6.

[41] Nasreen S, Haque M, Hossain M, Farid A. Nutrient uptake and yield of onion as influenced by nitrogen and sulphur fertilization. Bangladesh J Agric Res 2008; 32(3): 413-20. 
[http://dx.doi.org/10.3329/bjar.v32i3.543]

[42] Vachhani MU, Patel ZO. Effect of nitrogen, phosphours and potash on bulb yield and quality of onion (Allium cepa). Indian J Agron 1993; 3 : $333-4$.

[43] Amare G, Mohammed W, Tana T. Effect of plant spacing and np fertilizer levels on growth, seed yield and quality of onion (Allium cepa L.) at shewa robit, northern Ethiopia. Open Biotechnol J 2020; $14(1)$

[http://dx.doi.org/10.2174/1874070702014010012]

[44] Jilani MS. Studies on the management strategies for bulb and seed production of different cultivars of onion (Allium cepa $\mathrm{L}$.). $\mathrm{PhD}$ thesis. Gomal University, Dera Ismail Khan 2004; 1-499.

[45] Rezaei EE, Kafi MBM. Nitrogen and cultivated bulb weight effects on radiation and nitrogen-use efficiency, carbon partitioning and production of persian shallot (Allium altissimum Regel.). J Crop Sci Biotechnol 2013; 16: 237-44.

[http://dx.doi.org/10.1007/s12892-013-0076-8]

[46] Sharangi ABSP. Effect of placement and dose of phosphatic fertilizers on onion. J Plant Nutr 2009; 32: 1901-13. [http://dx.doi.org/10.1080/01904160903242383]

[47] Rizk FA, Shaheen AM, Abd El-Samad EA, Sawan OM. Effect of different nitrogen plus phosphorus and sulphur fertilizer levels on growth, yield and quality of onion (Ailium cepa $\mathrm{L}$.). J Appl Sci Res 2012; 8: 3353-61.

[48] El Hamady MM. Growth and Yield of Onion Alum cepa L. as Influenced by Nitrogen and Phosphorus Fertilizers Levels. Can J Agric Crop 2017; 2: 34-41.

[http://dx.doi.org/10.20448/803.2.1.34.41]

[49] Steer BT. The bulbing response to day length and temperature of some Australian cultivars of onion (Allium cepa L.). Aust J Agric Res 1980; 31: 511-8.

[http://dx.doi.org/10.1071/AR9800511]

[50] Syed N, Manir M, Alizai AA, Ghaffoor A. Onion shelf life as a function of the levels of nitrogen and potassium application. J Biol Sci 2001; 1(2): 71-3.

[http://dx.doi.org/10.3923/jbs.2001.71.73]

[51] Lemma Dessalegne and Shimeles Aklilu. Research Experiences in Onion production. Research Report No 55 Ethiopia Agricultural Research Organization 2003. Addis Ababa, Ethiopia.

[52] Ghaffoor A, Jilani MS, Khaliq G, Waseem K. Effect of different NPK levels on the growth and yield of three onion (Allium cepa L.) varieties. Asian J Plant Sci 2003; 2(3): 342-6.

[http://dx.doi.org/10.3923/ajps.2003.342.346]

[53] Burba JL, Galmarini CR. First international symposium on edible Alliaceae. International Society for Horticultural Science, Mendoza, Argentina.

[54] Yadav RL, Sen NL, Yadav BL. Response of onion to nitrogen and potassium fertilization under semi-arid condition Ind. J. Hort 2003; 60: 176-8.

[55] Nasreen S, Haque MM, Hossain MA, Farid ATM. Nutrient uptake and yield of onion as influenced by nitrogen and sulphur fertilization. Bangladesh J Agric Res 2007; 32(3): 413-20.

[http://dx.doi.org/10.3329/bjar.v32i3.543]

[56] Tekeste N, Dechassa N, Woldetsadik K, Dessalegne L, Takele A. Influence of nitrogen and phosphorus application on bulb yield and yield components of onion (Allium Cepa L.). Open Agric J 2018; 12(1): 194-206.

[http://dx.doi.org/10.2174/1874331501812010194]

[57] Yoldas F, Ceylan S, Mordogan N, Esetlili BC. Effect of organic and inorganic fertilizers on yield and mineral content of onion (Allium Cepa L.). Afr J Biotechnol 2011; 10(55): 11488-92. [http://dx.doi.org/10.5897/AJB10.2535]

[58] Piri H, Amir N. Effect of Different Levels of Water, Applied Nitrogen and Irrigation Methods on Yield, Yield Components and IWUE of Onion. Sci Hortic 2020 [http://dx.doi.org/10.1016/j.scienta.2020.109361]

[59] Pandey UC, Ekpo U. Response of nitrogen on growth and yield of onion (Allium cepa L.) in Maiduguri region of Borno State, Nigeria. Research and Development Reporter 1991; 8(1): 5-9.

[60] Kumar S, Sushant CP. Bulb yield and quality of onion (Allium cepa L.) as affected by application rates of nitrogen and potassium fertilizer. Agric Sci Dig 2006; 26(1): 11-4.

[61] Anwar MN, Sarker JU, Rahman M, Islam MA, Begum M. Response of onion to nitrogen, phosphorus, potassium, sulphur and zinc. Bangladesh Journal of Environmental Scences Aust J Basic \& Appl Sci 2007; 70: 68-72.

[62] Messele B. Effects of Nitrogen and Phosphorus Rates on Growth,
Yield, and Quality of Onion (Allium Cepa L.) At Menschen Für Menschen Demonstration Site, Harar, Ethiopia. Agricultural Research \& Technology: Open Access Journal 2016; 1(3): 1-8. [http://dx.doi.org/10.19080/ARTOAJ.2016.01.555563]

[63] Gupta RP, Sharma VP. 2000; Effect of different spacing and levels of nitrogen for production of export quality onion bulbs planted on raised bed. News Letter National Horticultural Research and Development Foundation 20(1-4): 13-6.

[64] Shaheen AM, Abdel-Mouty MM, Ali AH, Rizk FA. Natural and chemical phosphorus fertilizers as affected onion plant growth, bulbs yield and its some physical and chemical properties. Aust J Basic Appl Sci 2007; 1(4): 519-24.

[65] Morsy MG, Marey RA, Karam SS, Abo-Dahab AM. Productivity and storability of onion as influenced by the different levels of NPK fertilization. J. Agri. Res. Kafer El-Sheikh Univ 2012; 38(1): 171-87.

[66] El-Hamady MM. Growth and yield of onion alum cepa 1. as influenced by nitrogen and phosphorus fertilizers levels. Can J Agric Crops 2017; 2(1): 34-41.

[http://dx.doi.org/10.20448/803.2.1.34.41]

[67] Shege G, Melkamu A, Amare H, Yigzaw D. Economic and Agronomic optimum rate of NPS fertilizer for irrigated garlic (Allium sativum L) Production in high lands of Ethiopia Department of horticulture Debre Markose University,Burie campus. Ethiopia: Burie 2017.

[68] Cizauskas A, Viskelis P, Dris R, Oladele OI. Influence of nitrogen rates on onion yield, quality and storability. Moor Journal of Agricultural Research, (1): 85-89. Aust J Basic Appl Sci 2003; 2007.

[69] Mahmoud Asmaa R. Response of onion plants to minerals and biofertilizers application. Application Res J Agric \& Biol Sci 2006; 2(6): 292-8.

[70] Boyhan George E, Reid L Torrance. Effects of nitrogen, phosphorus, and potassium rates and fertilizer sources on yield and leaf nutrient status of short-day onions 2002; 42(3)

[71] Ghoname A, Fawzy ZF, El-Bassiony AM, Riadand GS, Abd El-Baky $\mathrm{MMH}$. Reducing onion bulbs flaking and increasing bulb yield and quality by potassium and calcium application. Aust J Basic Appl Sci 2007; 1(4): 610-8.

[72] Hansen SL, Henriksen K. Increasing the dry matter production in bulb onions (Allium cepa L.) Denmark Department of Fruit, Vegetable and Food Science 2001; 2: 147-52.

[73] Randle WM, Ketter CA. Pungency assessment in onions. Proceedings of the 19-workshop conference of the Association for Biology Laboratory Education (ABLE) 1998; 177-96. http://www.zoo. utoronto.ca/able/volumes/copyright.htm

[74] Schwimmer S, Weston WJ. Enzymatic development of pyruvic acid in onion as a measure of pungency. J Agric Food Chem 1961; 9: 301-4. [http://dx.doi.org/10.1021/jf60116a018]

[75] Shock CC, Feibert BG, Saunders LD. Plant population and nitrogen fertiliza- tion for subsurface drip-irrigated onion. HortScience 2004; 39(7): 1722-7.

[http://dx.doi.org/10.21273/HORTSCI.39.7.1722]

[76] Woldetsadik K. Shallot (Allium cepa var. ascalonicum) Responses to plant nutrients and soil moisture in a subhumid tropical climate Doctoral dissertation, Swedish University of Agricultural Sciences, Alnarp 2003; 1-28.

[77] Coolong TW, Kopsell DA, Kopsell DE, Randle WM. Nitrogen and sulfur influence nutrient usage and accumulation in onion. J Plant Nutr 2004; 27: 1667-86.

[http://dx.doi.org/10.1081/PLN-200026010]

[78] Shaheen AM, Omer N, Fawzy ZF. The effect of natural and / or chemical phosphorus fertilizer in combination with or without biophosphorus fertilizer on growth, yield and its quality of onion plants. Middle East J Agric Res 2012; 1: 47-51.

[79] Moustafa Y. Onion quality and storage ability affected by potassium humate and npk doses. EC Agric 2019; 5: 227-35.

[80] Biswas TD, Mukherjee SK. Text Book of Soil Science. 5th ed. New Delhi: Tata McGraw Hill 1993; pp. 170-97.

[81] Aqcuaye TMAJM, Rie HM. Potential and capacity of potassium in some representative soils of Ghana. Soil Sci 1967; 103: 79-89. [http://dx.doi.org/10.1097/00010694-196702000-00001]

[82] Tisdale SL, Nelson WL, Beaton JD, Halvin JL. Soil Fertility and Fertilizers. 5th ed. New York: Macmillan Publishing Co., Inc. 1995; pp. 109-229.

[83] El-Bassiony AM. Effect of potassium fertilization on growth, yield and quality of onion plants. J Appl Sci Res 2006; 2: 780-5.

[84] Yaso IA, Abdel-razzak HS. Effect of NPK fertilization on bulb yield and quality of onion under reclaimed calcareous soil conditions. J 
Agric Egypt Env Sci Alex Univ 2007; 6.

[85] EL-Desuki M, Abdel-Mouty MM, Ali AH. Response of onion plants to additional dose of potassium application. J Appl Sci Res 2006; 2: $592-7$

[86] Bolandnazar S, Mollavali M, Tabatabaei SJ. Influence of $\mathrm{NH}_{4} \mathrm{NO}_{3}$ and $\mathrm{K}_{2} \mathrm{SO}_{4}$ on qualitative characteristics of onion. Sci Hortic (Amsterdam) 2012; 136: 24-8.

[http://dx.doi.org/10.1016/j.scienta.2011.12.022]

[87] Boyhan GE, Torrance RL. Crop Reports Vidalia Onions- Sweet Onion Production in Southeastern Georgia 2002; 12

[88] Maisura M, Nurdin M, Muslina M. Effect of manure and NPK fertilizers on growth and production of onion (Allium cepa $\mathrm{L}$.). J Trop Hortic 2019; 2: 16

[89] Mohamed A, El-Damarany A, Marey R. Effect of planting dates and fertilization on yield and yield components of onion (Allium cepa L.) Grown from Sets J Plant Prod 2018; 9: 1031-44.

[90] Bekele M. Effects of different levels of potassium fertilization on yield, quality and storage life of onion (Allium cepa L) at Jimma, Southwestern Ethiopia. J Food Sci Nutr 2018.

[http://dx.doi.org/10.35841/food-science.1.2.32-39]

[91] Aftab Samra Hamid. Impact of potassium on the growth and yield contributing attributes of onion (Allium cepa L.) Asian Res J Agric 2017; 7: 1-4.

[http://dx.doi.org/10.9734/ARJA/2017/38322]

[92] Riad G. 2007.Reducing Onion Bulbs Flaking and Increasing Bulb Yield and Quality by Potassium and Calcium Application

[93] Marschener P. Mineral Nutrition of Higher Plants. Third Edit.. 2012.

[94] El-Morsy A, ElKasas A, El-Tantawy A. Onion plant growth and yield as affected by nitrogen, potassium and sulphur combinations under elarish region conditions. Sinai J Appl Sci 2016; 5: 345-62.

[http://dx.doi.org/10.21608/sinjas.2016.78657]
[95] Mozumder S, Moniruzzaman M, Halim G. Effect of N, K and S on the Yield and storability of transplanted onion (Allium cepa $\mathrm{L}$.) in the Hilly Region J Agric Rural Dev 1970; 5: 58-63.

[http://dx.doi.org/10.3329/jard.v5i1.1459]

[96] Singh SP, Verma AB. Response of onion (Allium cepa) to potassium application Indian J Agron 2001; 46: 182-5.

[97] Greenwood DJ, Stone DA. Prediction and measurement of the decline in the critical-K, the maximum $\mathrm{K}$ and total plant cation concentration during the growth of field vegetable crops. Ann Bot 1998; 82: 871-81. [http://dx.doi.org/10.1006/anbo.1998.0775]

[98] Mandal J, Acharyya P, Bera R, Mohanta S. Response of Onion to NPK, S and Micronutrients. Int J Curr Microbiol Appl Sci 2020; 9: 1137-44.

[http://dx.doi.org/10.20546/ijcmas.2020.906.141]

[99] Gamiely S, Randle WM, Mills HA, Smittle DA, Banna GI. Onion plant growth, bulb quality, and water uptake following ammonium and nitrate nutrition. HortScience 2019; 26: 1061-3.

[http://dx.doi.org/10.21273/HORTSCI.26.8.1061]

[100] Ali H, Taalab AS. Effect of natural and / or chemical potassium fertilizers on growth, bulbs yield and some physical and chemical constituents of onion (Allium cepa, L. ) J Agric Biol Sci 2008; 4: 228-37.

[101] Liu S, He H, Feng G, Chen Q. Effect of nitrogen and sulfur interaction on growth and pungency of different pseudostem types of Chinese spring onion (Allium fistulosum L.). Sci Hortic (Amsterdam) 2009; 121: $12-8$.

[http://dx.doi.org/10.1016/j.scienta.2009.01.019]

[102] Singh SK, Kumar MS, Singh PK, Yadav LM. Effect of sulphur sources and levels on growth, yield and quality of onion (Allium cepa L.). Curr J Appl Sci Technol 2020; 21: 1-4. [http://dx.doi.org/10.9734/cjast/2019/v38i630452]

\section{(C) 2020 Getachew Amare.}

This is an open access article distributed under the terms of the Creative Commons Attribution 4.0 International Public License (CC-BY 4.0), a copy of which is available at: https://creativecommons.org/licenses/by/4.0/legalcode. This license permits unrestricted use, distribution, and reproduction in any medium, provided the original author and source are credited. 